The Rise, Organization, and Institutional Framework of Factor Markets, 23-25 June 2005 http://www.iisg.nl/hpw/factormarkets.php

\title{
Land Markets in Late Imperial and Republican China
}

Kenneth Pomeranz

Chancellor's Professor of History, University of California Irvine

klpomera@uci.edu

Draft: please do not quote, cite or distribute without permission

Introduction: Issues of Time, Place, and Scope

Land has been changing hands for money since ancient times in China, often on a fairly large scale. The break-up of inalienable estates tied to aristocratic status and office-holding during and after the An Lushan Rebellion (755-763) made such transactions more common thereafter. A further sharp uptick occurred during the Ming dynasty (1368-1644), despite the government's preference for an immobile agrarian world: one finds a proliferation of land sale contracts, elite and government complaints about the increased commodification of land (and other things), and evidence that the government was having increased difficulty keeping its land registers up to date. (Brook 1998:63-4, 79, 95) It is also during this period that a new proverb appeared: "In 1,000 years, a piece of land has 800 owners." (Cited in Yang 1988: 30.) The Ming also brought a number of institutional innovations that made land transactions easier to initiate, and made it much more difficult to block land transfers by claiming other kinds of rights to the land; for these reasons, Yang Guozhen argues that by the late Ming, all the features that would characterize land markets during the Republic (1912-1949), were already in place. (Yang 1988: 30). And, as I will argue below, for the most part these markets functioned fairly well, especially in China's more developed regions;. Unusually intense agrarian problems, when they developed towards the end of the imperial period, were the result of bottlenecks in other sectors that limited off-farm employment and 
The Rise, Organization, and Institutional Framework of Factor Markets, 23-25 June 2005 http://www.iisg.nl/hpw/factormarkets.php

stresses exogenous to the economy per se. Even in the areas where agriculture

performance lagged, it is hard to see much reason to blame that on the structure or functioning of land markets.

By the early Qing period, a series of socio-economic changes had occurred which, though usually thought of as pertaining to labor rather than land, complemented Ming changes in land markets, and rounded out the context in which those markets worked: the vast majority of bondservants had been freed, and legally servile statuses largely abolished. The legal code had removed most differences in the treatment of different classes: it was, for instance, no longer a graver legal offense for a tenant to strike his landlord than vice versa (though other differences, e.g. between elder and younger relatives, remained). In some places, social expectations lagged behind these legal changes, so that tenants and laborers were still, for instance, expected to perform certain symbolic acts of deference; but these acts were rarely of much economic significance, and most seem to have faded with time as well.

The central features of the late $16^{\text {th }}$-early $20^{\text {th }}$ century land market to which Yang referred included the evolution of separate rights in subsoil ownership and topsoil ownership, with the latter confirming use rights to the land. By the 1500s, these rights could be bought, sold, or mortgaged separately. The rights of topsoil owners in particular gradually increased until they were comparable to those of subsoil owners; this resulted in what was often called the "one field, two masters" (yi tian liang zhu) system, which spread over much of China (particularly its most advanced regions) over the next few centuries. (See for instance Yang 1988: 91-133) The security of use rights in this system 
The Rise, Organization, and Institutional Framework of Factor Markets, 23-25 June 2005 http://www.iisg.nl/hpw/factormarkets.php

seems to have been important for encouraging investments by topsoil owners in land improvement: and in general it appears that it was topsoil rather than subsoil owners who made most of these investments. Though landlords and sometimes officials complained about the difficulties of removing tenants in arrears (particularly those who had purchased topsoil rights, but other tenants as well), the rental system in general seems to have been flexible enough that it did not inhibit investment in the land. Nor, contrary to some claims, did tenants have a sufficient degree of "subsistence security" to encourage them to maximize family size while satisficing in terms of income. ${ }^{1}$

It was also in the Ming that the major institution which slowed down many land transactions - the practice of "live sales" (as opposed to "final sales") in which a seller might have many years in which to try to buy back land he had sold before he lost all rights to the property - become widespread. (Yang 1988: 31-33; Macauley 1988: 230235). The effects of this system are less clear than those of the "one field, two masters" system, and need further investigation: in what follows, however, I will argue that it probably had more effect on land-holding as a marker of status than on incentives for production. The rest of this paper will focus on the period from these $16^{\text {th }}$ century innovations forward, emphasizing the Qing (1644-1912) period.

\section{Types of land}

An analysis of land markets can be roughly divided into the institutions surrounding land sales, rentals, and mortgages, though the lines between sale and mortgage (and occasionally even between rental and mortgage) were not always clear. The rules also sometimes differed a bit among types of land: farm land, timber land, grave land,

\footnotetext{
${ }^{1}$ For this view, see particularly Huang 1990 and Brenner and Isett 2002. I have already replied at some length to Huang in Pomeranz 2002, and see no need to repeat the discussion here; anyone interested in my response to Brenner and Isett (awaiting publication in a conference volume) should contact me directly.
} 
The Rise, Organization, and Institutional Framework of Factor Markets, 23-25 June 2005 http://www.iisg.nl/hpw/factormarkets.php

reclaimed land along the edges of lakes or rivers, urban real estate, etc. Some of the murkiest issues for historians are those that involve the initial acquisition of previously unclaimed property. Such acquisitions rarely left a contract for us to look at (since there was nobody "selling" such land), the statutes are not particularly detailed, and while there are a huge number of extant legal cases from which we can infer the principles at work, scholars have not yet gone through most of them. Issues about such land will come up periodically in this paper, but for the most part I will focus on transactions in which land that already had an owner was temporarily or permanently transferred.

The vast majority of land in Ming and especially Qing and Republican China was privately held. The early Ming state confiscated a good deal of land, but by the 1500s, most of this had drifted back into private hands. (R. Huang 1974: 99) The Qing likewise set aside some land in North China for the hereditary use of soldiers, Grand Canal boatmen, and the crown itself, but such holdings never amounted to more than than 3,500,000 acres, or perhaps 3\% of total arable. (P. Huang 1985: 99.) And much of that land, like the land confiscated by the Ming, also tended to drift into the private market, with its supposedly hereditary tenants often finding it easier to sell or mortgage it; indeed, when the government made a brief attempt to reassert state ownership of a small amount of this land in 1904, it faced furious (and successful) protests by peasants who had long treated these fields as ordinary private land. (Pomeranz 1993: 240.) In some particular places, the state also tried to assert public ownership of some land in environmentally fragile areas, but it was generally unable to enforce such claims. (Osborne 2004: 132, 152). 
The Rise, Organization, and Institutional Framework of Factor Markets, 23-25 June 2005 http://www.iisg.nl/hpw/factormarkets.php

A good deal more land was held in theoretically inalienable trusts by private entities: temples, schools, and especially lineage trusts (which used the income for educational, ritual, and other expenses on behalf of a extended kin group conceived of as having infinite life). But only the lineage trusts were quantitatively significant, and even then only in a relatively few places. And while lands "enclaved" in this way were more likely to remain off the market than those that were supposedly being kept off the market by the state, they too experienced a long-term tendency towards leakage into the market: this was particularly true of lineage-held grave lands, which were often up in hills that became increasingly tempting targets for exploitation as population rose, forests shrank, wood prices and rose, and American food crops offered new uses for land at high elevations. Most importantly for our purposes, even when ownership of these lands did remain outside the market, there was a lively market in use rights which shaped the way this land was used in production: the same kinds of rental contracts were concluded for them as for plots owned by households. While we have scattered examples of such plots being rented to kinsmen at a bit below market rates, there is no reason to think that the general pattern of land use and rental rates was very different from that governing other land in the same areas.

Other big questions concern variation across space. We know, for instance, that there was a lot of variation in local custom with respect to the redeeming of pawned land - a county by county compilation of such customs from an early $20^{\text {th }}$ century survey goes on for many, many pages. But nobody has yet done the detailed work to see how often these county to county differences were minor variations (e.g. differences in number of times one could extend the redemption date) and how often they represented more 
The Rise, Organization, and Institutional Framework of Factor Markets, 23-25 June 2005 http://www.iisg.nl/hpw/factormarkets.php

fundamental differences (e.g. extensions of the time for redemption being allowed in one place and strictly forbidden in another). So far, it seems to me that most of the local differences revealed in case studies are relatively small, though this is a preliminary guess. For the most part I will work at a much more general level here, emphasizing differences between relatively developed parts of South and East China (mostly in Southern Jiangsu, Zhejiang, Fujian, and Guangdong, plus bits of other provinces) on the one hand, and every place else on the other. The South and East had far more tenancy, but also far more protections for tenants, far more land owned by corporate entities (temples, schools, and especially lineage trusts), and a more complex system of property rights which allowed different rights in the same piece of land to be bought, sold, and mortgaged separately. I will not deal with the sometimes very different systems of landholding and land transfers among various non-Han peoples on the frontier. Despite their variety, complexity, and relevance to Chinese social history they affected relatively few people, and probably even less of China's agricultural production: as population density grew and more intensive farming took hold in frontier regions, their systems for property ownership, use and transfer generally became more and more like those of "China proper."

\section{The State, Taxation, and Ratification of Land Claims}

Households farming land and paying taxes on it were always recognized by the state as having ownership rights, and thus the ability to sell the land if they wished. This was true even in some cases in which the original title to the land might have been somewhat murky - e.g. if somebody reclaimed abandoned land and then the original owner returned. If the original owners returned within a specified time frame, they would 
The Rise, Organization, and Institutional Framework of Factor Markets, 23-25 June 2005 http://www.iisg.nl/hpw/factormarkets.php

probably receive a share of the land, but not all of it; and after a long period of time, their rights lapsed entirely. Indeed tax payments established such a strong claim to land that tax payments could sometimes convert even illegally occupied land into property protected by the government. (Osborne 2004: 121, 127.) Originally, this practice probably stemmed from both the desire to encourage increased cultivation and a desire for greater revenue: claims were considered weaker if somebody had occupied land but was not farming it (Osborne 2004:136). However, it continued even after land tax quotas had become fixed (in 1712-3) and after the Qing had begun to worry that land reclamation had gone too far and was beginning to create serious environmental problems. (The dawning of this realization varied from place to place, but it was widespread by the turn of the $19^{\text {th }}$ century.) Land confiscations were extremely rare, even when legal actions of various sorts made the state aware that landowners had committed serious infractions.

Since non-agricultural land was generally not taxed, claims to that land were sometimes harder to verify. Of course, such land was also less likely to change hands: grave lands, for instance, were intended to remain in the family forever, were negligible as a factor of production, and were generally sold only as a matter of economic necessity. When they were sold, however, these sales do not appear to have been handled very differently from other sales.

A more common phenomenon, especially in the $18^{\text {th }}$ and $19^{\text {th }}$ centuries, was the long-term renting out of what had been non-agricultural land, propelled by population growth, on-going commercialization, intensifying lumber shortages, and in some cases the availability of new crops that would grow on previously uncultivable soils (potatoes 
The Rise, Organization, and Institutional Framework of Factor Markets, 23-25 June 2005 http://www.iisg.nl/hpw/factormarkets.php

high up on hillsides, peanuts on sandy soil, etc.). Often these lands were owned by units

larger than households: lineages (especially in the case of gravelands), temples,

academies, etc. In many cases they were rented out to new users illegally: a group of

junior kinsmen, for instance, would sometimes represent themselves as having the

authority to lease out lineage lands for which they were not the actual managers. This

was particularly common in the renting out of hillside tree and gravelands to immigrant groups who sought to log it and or turn it into farm land. Interestingly, despite the fact that such transactions were both illegal and increasingly recognized as contrary to the public (environmental) interest, the rights of the renters were routinely upheld if they had a contract: unless the lineage could repay the rent deposit (which they rarely could), the tenants had to be allowed to complete their lease period (sometimes as long as 30 years), whatever the harm might be to the unwitting members of the lineage. The only tenants ever evicted before their leases were up were those who had been involved in violence. (Osborne 1989, 1994, 2004).

Sometimes hillside or other "waste" land did change owners (not just users) as it became farm land: either through legitimate sale or some kind of usurpation. The latter category included encroachment on unused land without knowledge of the owner, but with payment of proper fees to the state, or "purchase" from an owner who turned out to lack the legal right to sell. When such cases came to light the new occupier usually had to make some payment to the original owner (unless he had already paid money to somebody who had plausibly claimed to be the owner, in which case that person became liable for the true owner's loss). However, the new owner/improver was rarely completely dispossessed, and the labor he had done in developing the land was generally 
The Rise, Organization, and Institutional Framework of Factor Markets, 23-25 June 2005 http://www.iisg.nl/hpw/factormarkets.php

seen as entitling him to some sort of return. And as noted before, if the person involved succeeded in getting the land on the tax rolls, he strengthened his claim considerably; with tax rates low, county quotas fixed after 1713, and local government personnel stretched thin, this sometimes created the unusual spectacle of people who were farming land without any tax liability paying bribes to insure that they would henceforth be taxed, against the policies of local governments. (This was especially likely in cases where a number of households were involved in clearing a piece of land, without a written contract among them, as the first household to come forward and register for taxation might, in the absence of other documentation, get more than its share of the land.) Over time, the idea behind this policy - that extending cultivated area was good in itself, and should be rewarded - came to be strongly questioned, for ecological reasons; but even then, as in the case of illicit hillside rentals, officials would not deprive illegal reclaimers of all the fruits of their labors.

\section{The Institutions of Land Markets:}

\section{Contracts}

Contracts have a very long history in China, and became more and more common over time. By late Ming and Qing times they were a routine part of land transactions; printed, standardized forms for sales, rentals, and mortgages of various sorts spread across the country. (See e.g. Cohen 2004; Osborne 2004; Yang 1988.) Land contracts tended to become more detailed over time, specifying at greater length what would happen in certain circumstances: people seem to have preferred specifying outcomes under various scenarios to relying on either state or private adjudicators to decide what 
The Rise, Organization, and Institutional Framework of Factor Markets, 23-25 June 2005 http://www.iisg.nl/hpw/factormarkets.php

would be fair. Even in ancient times, contracts seem to have been framed with the goal of preventing third parties from intervening. Because property, as we will see, generally belonged to households, not individuals, making sure the transaction was safe from relatives of the seller was a particular concern. (In ancient times, this had included fending off interference from dead relatives: land sale contracts from the Han dynasty include provisions to incorporate unknown people who might be buried on the land into the ancestral line of the buyer, so that they will be provided for in the underworld and have no reason to complain. See Scogin 1990: 1342-43, 1354.) At the same time, the contract created a bond (one meaning of yue, for "contract" is "bind" or "entangle") of sorts between the contracting parties, signifying an "ongoing relationship" with moral significance (Scogin 1990: 1370-84) in which the parties made law for themselves with heaven as their witness; emphasizing the strength of the relationship between the contracting parties served, among other things, to highlight the exclusion from this arrangement of everybody else. The goal of using contracts to create all kinds of binding agreements safe from the interference of others was widely accepted as appropriate (Hansen 1995), and other entities, including the state, seem not to have interfered much, whether in early or late imperial times.

Generally when the state was approached (through a lawsuit) to decide a property dispute, they would affirm what was in the contract unless it was clearly contrary to the law or simply didn't cover the situation that had arisen. (In theory land transfers were not legal unless they were registered with the state and stamped, but magistrates routinely upheld unstamped contracts.) When, as often happened, magistrates sought to have a case mediated by others rather than deciding it themselves, they seem to have usually 
The Rise, Organization, and Institutional Framework of Factor Markets, 23-25 June 2005 http://www.iisg.nl/hpw/factormarkets.php

chosen the middleman in the original contract as mediator; assuming that this pattern was well-known, contracting parties were effectively choosing the forum for resolving many contract disputes when they made the contract. Mediations initiated by the parties themselves probably also often started with the middleman, though we have no way of knowing whether the cases we are aware of where that happened were typical. Contracts did not get struck down for unconscionability (in contemporary U.S. law, the notion that some contracts are simply so one-sided as a result of informational or other asymmetries that they should be voided even if they were freely agreed to) as far as I can tell, unless they were not actually illegal. Nor, despite high rates of illiteracy, did they get struck down on grounds that one party didn't know what they meant. People seemed to have had great faith in the power of contracts, even signing contracts to cover transactions that were blatantly illegal, and which they therefore presumably did not expect to see enforced by magistrates (see for instance Osborne 2004: 156, involving written contracts to cover up murders in exchange for hush money). Fortunately for historians, this faith in contracts has also often resulted in people holding on to contracts long after legal changes (including the Communist land reform) that invalidated any claim that could be based on these contracts, at least in the eyes of the state. (The result is that huge numbers of old contracts are now being found by field researchers, promising to dwarf the numbers we have found preserved in archives.) Practically, people probably expected most contracts to be enforced by the community if need be, rather than the state, and thus spelled out contractual terms only to the extent that there might be any doubt about them in community's eyes. Thus, for instance, "normal" marriages had no contracts about 
The Rise, Organization, and Institutional Framework of Factor Markets, 23-25 June 2005 http://www.iisg.nl/hpw/factormarkets.php

issues such as which lineage the children would belong to, while uxorilocal marriages

spelled this out in detail (Cohen 2004: 59-60).

Households, Lineages, and Property Transactions

Private property in Late Imperial and Republican China was generally seen as belonging to a household, not an individual. (Zelin 2004: 20, 31-32.) There was an exception for property that entered a household as part of the wife's dowry: this was still held to be her property, though under normal circumstances she was supposed to place it at the disposal of her household. This one example of individual property sometimes provided a loophole for transferring other property to individual hands, too, but such cases were limited. (Zelin 200: 33; ) And since the household to which property belonged was in principle eternal, each household head was really more a custodian of its land and other property than its possessor. This principle was occasionally invoked to invalidate a transaction when the head of the household and the person who, in practical terms, tended to represent it in transactions were not the same person -- e.g when a widow was household head and her son tried to sell family land (see e.g. Osborne 2004: 145 ) - or even more rarely, when a transaction was very obviously calculated to benefit the individual at the expense of the household (e.g. selling land in order to get money with which to abandon one's family). In most cases, though, the ability of the household head to buy and sell on behalf of the household was not at issue. The situation became more complicated when land belonged not to the individual household, but to a larger lineage.

There was some land that unambiguously belonged to lineages, having been placed in lineage trusts through a formal legal process documented by written agreements 
The Rise, Organization, and Institutional Framework of Factor Markets, 23-25 June 2005 http://www.iisg.nl/hpw/factormarkets.php

and approved by the local government. These situations were in principle quite clear: the trust was established for stated purposes (educating orphan sons, supporting widows, maintaining a lineage temple, etc) and had a single, known head at any given time (usually the eldest living member of the descent line of first sons). Reality could be more complicated: lineage heads might try to avoid committing the property to its legally required uses and need to be threatened with litigation (e.g. Dennerline 1986: 191-4, 202), or kinsmen might falsely represent lineage land as belonging to their household, or usurp authority to act for the lineage. (See e.g. Osborne 1994: 11, 13, 19). But these were clearly violations of practices upheld by both law and custom, and treated like any other misappropriation of property. More complicated cases involved attempts by kinsmen to intervene in situations where no lineage trust had been legally established - so that the property belonged to some specific household - but where at least some people felt nonetheless that a larger lineage had some legitimate interest at stake.

As far as we know organized lineage activities for commoners did not appear until Song times, and even then did not spread rapidly. Formally incorporated lineage organizations were even rarer, and did not become very common in any significant part of the country until the Ming - though more informal activities, such as recording genealogies, were more common from Song times forward. Even in the Ming and Qing, strong corporate lineages were largely restricted to the South and East, and far from universal even there. But where lineages did become strong they tended include members of all social strata, and thus often with divergent economic interests. (See e.g. Szonyi 2002 ) 
The Rise, Organization, and Institutional Framework of Factor Markets, 23-25 June 2005 http://www.iisg.nl/hpw/factormarkets.php

Moreover, despite the limited extent of formally incorporated lineages, the feeling that some kind of extended kinship was important was extremely common in late imperial times. Even in rural North China, where lineage organizations with significant amounts of property were very rare, $20^{\text {th }}$ century surveys make it clear that many important decisions - about place of residence, adoptions, the sharing of resources in crises, etc -- were strongly influenced by lineage ties and by certain important aspects of lineage ideology, such as the notion that no branch of the descent line should be allowed to die out if this could possibly be avoided. (See e.g. Duara 1988: 86-117) Among Chinese bannermen in Southern Manchuria - admitted a rather unusual, though welldocumented, group - the influence of lineage is clearly traceable in all the basics of material life: the status of paternal uncles, for instance, has a significant statistical influence on age at marriage, number of children, etc., even once the status of fathers is controlled for. (Campbell and Lee 2003)

Under the circumstances, it would hardly be surprising that kinship ties would often play a role in decisions about land, the most important productive asset in the economy people who might wind up responsible for each other in some way, and felt that was appropriate, would have all sorts of reasons to think about buying, selling, renting, and mortgaging land in ways that might strengthen or at least not weaken those ties. Moreover, land - both farmland and graveland - often played a role in determining membership in a village (see e.g. Duara 1988: 207-213), which could be useful in many circumstances, including strengthening a person's claim to nearby waste land he might want to reclaim. This was yet another reason why one might find it useful to actively maintain ties to both living and dead kinsmen and consider the desirability of doing so in 
The Rise, Organization, and Institutional Framework of Factor Markets, 23-25 June 2005 http://www.iisg.nl/hpw/factormarkets.php

one's other decisions. But to see kin membership as a resource people wished to safeguard (or extend), and so considered in analyzing their self interest, is quite different from seeing kinship as having prevented people from participating in markets based on their self-interest. And while some scholars have suggested that the power of lineages seriously constrained the operations of the land market, the actual evidence for such a claim is thin indeed, at least for the late imperial period.

In the Song and Yuan dynasties, contracts often included language to the effect that the seller was required to post notices giving people (presumably both kin and holders of liens on the land) the right to object before the sale went through. In the Ming these provisions disappear, replaced (for kin matters) by the seller's assurance that he has consulted his kin. (Yang 1988: 31.) How significant was this need for "consultation"? On the one hand, contracts for land sales routinely mention that the seller has first offered the land to his close male relatives before selling to somebody else, and we have some instances in which we know these relatives were paid money to assent to transactions. (Buoye 2000: 185; Ocko 2004: 197) On the other, this right of first refusal by close male kin is not in the law and would certainly not be enforced by the state: on the contrary, Ming and especially Qing law was quite firm on the point that the co-resident household was the crucial unit for property-holding and economic decision-making, and rights to interfere with that were granted with great hesitation. (The rights of co-resident kin, such as an elderly parent ignored by his or her adult son, was potentially a different matter.) There are no recorded instances that I am aware of in which a right of agnates to buy land their relative was selling was successfully invoked to keep land in the extended family (as opposed to invoking it to extract payment.) Furthermore, the idea of offering land to kin 
The Rise, Organization, and Institutional Framework of Factor Markets, 23-25 June 2005 http://www.iisg.nl/hpw/factormarkets.php

first seems to be absent in contracts for land use rights (see examples in Yang 1988: 33-4) and in contracts for land swaps (Cohen 2004: 47). ${ }^{2}$ Even in a contract in which the seller says he offered the land in redeemable ("live") sale to his close agnates before turning to an outsider, he does not seem to have had any obligation to offer it to kin in outright sale before contracting a redeemable sale with an outsider. (Cited in Cohen 2004:49.) Sicne these live sales were not usually redeemed, much land could pass to non-kin thatway. Moreover, the phrasing of many contracts (especially those connected with "live sales") with respect to agnates is interesting, saying that henceforth "they will have nothing to say" about the land in question. While the literal content conveyed by those words may be little different than what would be conveyed by "they have given their final consent," the tone is nonetheless suggestive: it puts them outside rather than inside the community formed by the contracting parties (which will, in the case of a live sale, continue to interact until the land is definitively transferred or repurchased).

It thus appears that while some sense of land as a patrimony belonging to an extended family unit may have lingered into the Qing, it was a) increasingly weak and b)not a very relevant factor with respect to land as a factor of production. (For that purpose, a vibrant rental market would suffice, even if the market for subsoil rights had been very restricted; the case of early modern Britain may be an instructive example

\footnotetext{
${ }^{2}$ Huang (1990: 107) claims that in the Yangzi Delta, topsoil rights almost never changed hands, citing a 1940 survey in which residents remembered few such sales. He then argues, somewhat peculiarly that "it was topsoil rights that carried the traditional constraints of extended rights of redemption in any conditional sale, and of the customary prior right of purchase by kin and neighbors in an outside sale," though it is hard to see how we would know this if such sales almost never occurred. At any rate, the number of contracts for such transactions (see for instance Zhou and Xie 1986: 311-317) and of archival records of conflicts that followed from them, make this extremely unlikely. So does the close fit that we find in Buck's data for the Delta between the number of laborers a family had and the size of the farm it worked (as opposed to owned): it is hard to see how this would happen without an active market in use rights. (Buck 1930: 114.) Various Qing sources also suggest, more anecdotally, that the size of the farms families worked corresponded closely to their available labor power; indeed, Huang's own argument about necessity-driven labor intensification would seem to require something like this.
} 
The Rise, Organization, and Institutional Framework of Factor Markets, 23-25 June 2005 http://www.iisg.nl/hpw/factormarkets.php

here.) In Buoye's study of property disputes that led to violence in Guangdong (2000), and in Macauley's study of the involvement of lineages in violent property disputes in Fujian (1998), the common issues involve boundary disputes, disputed rights to land reclaimed without government approval, conflicts over land that was pawned or offered for redeemable sale, and conflicts over the eviction of tenants. But even in these provinces, which probably had the strongest lineages in the empire, one does not find legal cases that resulted from those lineages using force to make the head of a particular household to offer land to his relatives first. Undoubtedly, people sometimes felt pressure in that direction, and often could see, even without pressure, that it was in their self-interest to please their kinfolk, but it is significant that when people decided otherwise, this does not seem to have provoked a coercive response. Finally, it is worth remembering that the places where any such pressure would have been strongest -- in the single surname villages of the Southeast Coast - would also have been places in which relatively few potential buyers would have been excluded by a requirement that land be offered to kin first.

\section{$\underline{\text { Middlemen }}$}

Land-related contracts, like other contracts in late imperial China, usually include the name of a middleman, or occasionally more than one. The role of those middlemen, however, is not always clear. The very detailed Chügoku Nōson surveys, done by Japanese investigators in occupied North China in the late 1930's and early 1940s, generally interpret the middleman as a guarantor, whose status and attitude could influence the terms of the transaction, and who might bear significant responsibility if 
The Rise, Organization, and Institutional Framework of Factor Markets, 23-25 June 2005 http://www.iisg.nl/hpw/factormarkets.php

something went awry. (For a summary of the Chügoku Nōson materials on this topic, see

Duara 1988: 181-191.) While middlemen were, logically enough, less important in land contracts than, for instance, in contracts for loans unsecured by land, they were still said by the interviewees to have played a number of important roles. They examined the land in question to make sure it was as described, affirmed that there were no completing claims on it (by questioning neighbors), helped negotiate the price, helped to dun delinquent tenants (in cases of rental contracts), and sometimes even guaranteed the rent itself. (Since in purchases payment was made at the time of a sale, that was not an issue in these cases.)

However, the middleman's role appears to be much smaller in the Qing contracts and archival cases that I have seen or read summaries of. Though he generally helped bring the parties together and received a fee, his ultimate role was more that of witness than of guarantor. No Qing contracts that I know of specifies that he bears any responsibility in the event of a problem with the transaction -- any liens or other problems that surface after the transaction are always said to be sole responsibility of the seller (see Cohen 2004:44 for an example in English). Nor do I know of any legal case in which a middleman was forced to take financial responsibility for such an error, though Osborne cites one in which a middleman was punished by a magistrate for a different misdeed: allowing somebody to sell his widowed mother's land without verifying that she had given her permission. (Osborne 2004: 145.) The only activities other than introductions (and perhaps price negotiations, which are not mentioned in the contracts) that we see middlemen regularly undertaking are 1) gathering the neighbors to determine the boundaries of the field to be sold (Buoye 2000: 186); 2) attempting to mediate post- 
The Rise, Organization, and Institutional Framework of Factor Markets, 23-25 June 2005 http://www.iisg.nl/hpw/factormarkets.php

contract disputes; and 3)approaching the purchasers if the seller in a "live sale" of land

later seeks an additional payment (to be discussed below). There was, however, one other activity sometimes thrust upon them: in the event of a lawsuit or criminal action arising out of a transaction they had been involved in, they were likely to be interrogated (sometimes a very unpleasant experience) to ascertain the parties' intentions and/or community practice (Osborne 2004: 145-6).

To what extent, then, did middlemen actually interject a "community" voice capable of modifying land transactions? Probably not that often. First of all, it is noteworthy that the use of middlemen in land transactions was not a hoary tradition extending back into a distant communal past; it appears, on the contrary, that it did not become widespread until the Qing dynasty. (Yang 1984; Buoye 2000: 151.) ${ }^{3}$ To that extent, it may well represent primarily the mobilization of community resources to minimize transaction costs and make markets work in a commercializing world where government land registers were often outdated and/or difficult to access, and government adjudication often expensive and difficult to access (if not as difficult or expensive as we once thought ${ }^{4}$ ), rather than the continuing influence of an earlier "moral economy." Secondly, the middleman was usually chosen by the party initiating the transaction (usually the seller in a land sale, or the person seeking a tenancy in a rental); while he clearly had to be acceptable to the other party, or no transaction would occur, he approached that person as a representative of the other (generally weaker) party. In

\footnotetext{
${ }^{3}$ Ancient land contracts generally refer to "witnesses" and do not assign these people any responsibilities at all. Credit contracts were more likely to refer to a "responsible" witness, guarantors being more important when a vital part of the agreement (repayment) was to be performed in the future. Scogin 1990: 1351-2.

${ }^{4}$ The literature on litigation and civil justice in Qing China has become enormous in the last 20 years, and is very contentious. It is hard to find anyone in the current debates, however, who upholds the old idea that Chinese were so terrified of the magistrate's yamen that they avoided litigating at all costs.
} 
The Rise, Organization, and Institutional Framework of Factor Markets, 23-25 June 2005 $\mathrm{http} / / /$ www.iisg.nl/hpw/factormarkets.php

Sichuan, for instance, people seeking a tenancy did not generally use middlemen until the late $18^{\text {th }}$ century, when empty land had become scarce and continued high rates of population growth had made it possible for landlords to become increasingly choosy (Buoye 2000: 179). Thus, to the extent that the middleman did seek to soften the outcome of market mechanisms, he probably did so as spokesman for a particular interest who felt he needed the help; it was not that everyone had always thought that a middleman should regulate these transactions. While this did not eliminate the middleman's ability to affect the terms of the agreement - at least when he was a person of enough substance in the community that one had to care about good relations with him (which he sometimes was and sometimes wasn't) - it means we must distinguish his influence from an expression of shared village norms per se.

Moreover, one of the main ways in which middlemen did modify contractual terms was in negotiating supplemental payments in "live sales" - to be discussed below. This, too, could be seen as a way in which he helped the two parties deal with a future complication they could anticipate in such a transaction, and which would require some adjustment to protect both of them (from utter destitution on one side, from extortionate demands on the other). As Buoye shows at length, criminal cases strongly suggest that over the course of the $18^{\text {th }}$ century, people became more comfortable with the idea of land as just another commodity, so that by the end of the century, people willing to stand up for the idea that it should be treated as an inalienable patrimony (and thus that extensions on the redemption of live sales should be granted almost forever) had probably become a small and beleaguered minority (Buoye 2000: 181-2); yet some 
The Rise, Organization, and Institutional Framework of Factor Markets, 23-25 June 2005 http://www.iisg.nl/hpw/factormarkets.php

requests for extensions and/or supplemental payments were still acceptable, and within these shifting bounds, sellers and middlemen continued to push their claims.

Thus, while they clearly needed to operate within community norms, there does not seem to be much reason to see the middlemen in land transactions as having privileged access to them. The Chīgoku Nōson investigators, whose main purpose was to understand village customs and community, may have been inclined to see middlemen as expressions of that community more than was actually the case; and Duara, whose main concern was to trace the decline of legitimate "traditional" authority in the $20^{\text {th }}$ century countryside, also had reasons to see middlemen as more of an expression of that community than I expect they were, and less as the agents of particular individuals trying to work out an advantageous deal across barriers of inadequate information, uncertain futures, and sometimes differences in power. (Duara's other point - that when middlemen succeeded in smoothing the way for mutually beneficial transactions and protecting the dignity of weak parties, they helped to build legitimate local authority - is quite likely true nonetheless, and quite important, but that is not our concern here.)

It is, of course, also possible that the role of the middleman in Qing contracts and legal cases was greater than the written record suggests, but there is no particular reason to think so. Another possibility, which seems to me more likely, is that the very unsettled political conditions in the early $20^{\text {th }}$ century, the sharp increase in fees charged by local government for notarial and other services after 1900, and the relative weakness of extended kin groups in the North all made it more important to have the middleman in that particular time and place play particularly active roles in guaranteeing land transactions, while the increasing numbers of very poor "semi-proletarians" (P.Huang 
The Rise, Organization, and Institutional Framework of Factor Markets, 23-25 June 2005 http://www.iisg.nl/hpw/factormarkets.php

1985: 294-8) in $20^{\text {th }}$ century North China may have also increased the number of landsellers and tenancy seekers who needed somebody to shape transactions so that they would do better than their objective bargaining position would dictate. When middlemen could not meet all these demands, they did indeed undermine their own claims to local leadership, as Duara suggests; but they were probably failing at relatively new tasks, not at ones that their predecessors had succeeded at.

Land-pawning and "live" sales:

Perhaps the most distinctive feature of real property law in China (and Vietnam) was the institution of "live sales," which extended the process of sale over a long period of time, giving the seller many opportunities to buy back land he had sold. "Live sales" (huomai) were sometimes also referred to as "conditional sales" (dianmai). That the latter term was often shortened to dian -- a term also used for the related but not identical transaction of pawning property - does not make our interpretive task any easier.

The relatively few land sale contracts that survive from Song and Yuan times (960-1368) are all for sales as we understand that term: the seller receives a payment agreed upon at the time of sale (even if it might be paid in installments) and has no further claim on the land thereafter. (Niida 1960: 2:376-7; Yang 1988: 273, 276.) However, by the middle of the Ming, a majority of the land contracts (almost all from Fujian) studied by Yang Guozhen are instead for conditional sales. In these transactions, the seller received less than the full market of the value of the land, while the buyer took control of the property; however the seller retained the right to refund the purchase price and regain the land within a certain period of time (sometimes as short as three years, sometimes as long as thirty). To this extent, the transaction resembled pawning a piece 
The Rise, Organization, and Institutional Framework of Factor Markets, 23-25 June 2005 http://www.iisg.nl/hpw/factormarkets.php

of movable property. But unlike a pawn shop, which can normally simply seize an item that is not redeemed within some particular time, the purchaser in this case would have to make an additional payment in order to take complete control of the land; in some cases this is specified in the contract, in some cases it appears to be a matter of local custom. The amount of this future payment - or, in many cases, payments, since the practice of "adding value" was often repeated 2, 3, or occasionally even more times before the seller lost all claims - was not generally specified in the contract, but negotiated. By the early Qing these extra payments were common enough that standard forms existed for contracts covering them (Yang 1988: 34). In some cases, these supplementary payments were said to reflect not just the difference between the original price paid and the full purchase price of the land at that time, but the increased value of the land since the initial transaction. (Yang 1988: 231-234; Buoye 2000: 96; Macauley 1998: 230-233.)

These "living sales," then, would seem to have introduced considerable uncertainty for the buyer, and to have denied him of some of the speculative benefits we would expect a purchaser to receive (while still bearing the risk of a market decline). It is not clear to me whether the purchaser could claim the full value of any improvements that he had made in the event that the land eventually returned to the seller. Since most of Yang's contracts come from Fujian, this was probably not an issue very often. Most of the land acquired in this way would be rented out rather than farmed by the buyer - in fact the seller would often stay on as the tenant - and, as we shall see, tenants rather than landlords tended to make most of the capital improvements to land, especially in relatively developed regions such as Fujian. Perhaps, in fact, this was not an important issue anywhere -- it appears that successful redemption after the initial contract period 
The Rise, Organization, and Institutional Framework of Factor Markets, 23-25 June 2005 http://www.iisg.nl/hpw/factormarkets.php

had expired was rare, and that what happened more often is that the new owner had to make additional payments to finally terminate all of the seller's claims on him - but until we have a more systematic survey of these cases we cannot be sure.

We also know that in both Guangdong and Fujian, where these sorts of sales were fairly common, disputes that erupted when sellers attempted to keep open the window for redemption longer than buyers were willing to let them accounted for a significant percentage of the Qing dynasty homicide cases arising from disputes over land sales (Buoye 2000: 92-95; Macauley 1998: 230-243) - though we must put that in perspective by recalling that land sales in general led to less violence than tenancy disputes, boundary disputes, or water rights disputes. Indeed, it seems likely to me that the social disruptions caused by people arguing over the extent of their obligations under "live sales" was probably more important than their economic effects in a narrow sense. But that, too, remains to be proven.

"Living sales" were routinely condemned by Qing officials, who attempted at various points to either ban the practice or transform it by creating a firm deadline for all claims; these attempts were only partially successful, however. But before looking at the historical trajectory of these unusual contracts, and their possible implications for understanding China's land market more generally, it is necessary to distinguish this kind of transaction from other kinds of land pawning, particularly in North China. In the North and Northwest, CCP land reform teams in the 1940s found that many peasants had transferred their land through a kind of dian which was much more favorable to the buyer than in South China live sales. The seller received half to two-thirds of the market price of the land, and the right to redeem the land by repaying this money within three years; 
The Rise, Organization, and Institutional Framework of Factor Markets, 23-25 June 2005 http://www.iisg.nl/hpw/factormarkets.php

any further extensions were apparently at the discretion of the buyer. (Pepper 1978: 266-

7) When extensions were granted, the original loan continued to accrue interest, at the high rates typical in the North China countryside; this generally made redemption impossible, and I have found no mention of the requests by peasants for extra payments that were typical parts of "living sales" in more prosperous areas. Thus it seems more likely that dian in these regions reflected a desperate clinging to land (or at least to cultivation rights) by poorer peasants in areas with increasing land hunger and few alternatives to farming. By not foreclosing and allowing the borrower to remain as a de facto tenant (though he officially paid "interest" rather than "rent"), creditors who planned to rent out any land they acquired anyway were able to get land at distress sale prices and avoid the difficulties that might have gone along with evicting a tenant and looking for a replacement. The presence of supplementary payments in live sales in richer areas gives that institution a very different flavor, with some scholars much more inclined to see the prevalence of such sales as a concession wrung from the rich by the poor (e.g. Yang 1988: 237-241) and even to wonder whether it posed a significant barrier to efficient land markets and capital accumulation. It would be hard to see dian transactions in the North that way.

Feng Shaoting (2004) argues that in urban real estate transactions in Shanghai, there is a trend over the course of the Qing towards fewer supplementary payments and a shorter timespan between the first and the final transaction. However, the quantitative trend in his data is not very strong. Feng also provides some contracts in which it appears that the supplementary payments were anticipated at the time of the initial contract, and were thus really part of the original price. He further suggests that where unanticipated 
The Rise, Organization, and Institutional Framework of Factor Markets, 23-25 June 2005 http://www.iisg.nl/hpw/factormarkets.php

multiple payments did occur, this often reflected attempts by middlemen to maximize their own fees by multiplying transactions. While this may well be true in some cases, it does not really explain the middlemen's success at getting these extra payments. No government agent would have upheld demands for supplementary payments, except where provided for by contract: indeed, Qing and Republican authorities were on record strongly opposing this practice. In the case that Feng discusses at greatest length, the three contracts signed when payments (after the first one) were made do not even make a consistent claim that this should be thought of as part of the sale price: they instead refer to the seller "pleading" for a "compassionate loan." We only know these were not really separate "loans" because the contracts make no mention of interest or the term for repayment, and because the third and final contract refers to the seller having already received "supplemental sale prices." (Feng 2004: 218-221.) And late Qing Shanghai was hardly a "village society" in which one would expect community pressures for "moral economy" to be especially strong.

What the interchangeable use of "supplemental sale price" and "compassionate loan" suggests, I think, is that the sellers in these transactions were not really getting a continuing claim on a specific plot of land in return for foregoing receipt of the full sale price; they were getting a custom-based claim on the consideration of the person (or household or other corporate entity) who had acquired their land, in an environment in which they may have had few other potential patrons. (While one should not make too much of claims for enduring "tradition," such claims can be seen as a remnant of the early idea of contracting parties creating an ongoing reciprocal bond by the act of contracting.) Certainly there is no sign that the additional payments requested, which are 
The Rise, Organization, and Institutional Framework of Factor Markets, 23-25 June 2005 http://www.iisg.nl/hpw/factormarkets.php

quite small, had anything to do with the skyrocketing value of land in Shanghai during the years in question (on which see Feng 2004: 222-3). Of the 13 contracts involving supplemental payments provided by Feng, 11 make explicit reference to the recipient being in financial need; so does the pre-printed form for a live sale transaction that he found in the Shanghai Municipal Archives (2004: 217-8). Many of the contracts are also full of deferent, pleading language, in which the recipients admit that they have no legal grounds for seeking additional money and say that it is "hard to bear" having to make such a request. By contrast, only one of the contracts mentions (along with a claim of hardship) that the seller feels that he "miscalculated" the price in the initial transaction; this document is dated only one month after the initial contract (Feng 2004: 210), and as Feng argues in another context, contracts made for supplemental payments so soon after the initial payment were probably actually signed (and post-dated) at the time of the initial transaction (216).

The element of uncertainty about the total amount of money a seller might ultimately demand in "live sales" might seem to be a significant disincentive to purchase land in the first place, and thus a serious impediment to an efficient land market. However, I suspect that there is less here than meets the eye. After all, no buyer had to purchase land through a "living sale"; "permanent sale" always existed, but cost more. Various scholars have estimated that the payment made at the time of a "living sale" was usually $60-80 \%$ of what the price for outright sale would have been (McAleavy 1958:406; Buoye 2000: 94; Macauley1998: 231). Given the high interest rates prevailing in the Chinese countryside, a seller could make two or three future payments (which, in the cases I have seen, always decline in absolute size over time) and still be getting a 
The Rise, Organization, and Institutional Framework of Factor Markets, 23-25 June 2005 http://www.iisg.nl/hpw/factormarkets.php

good deal. In a case for which Yang Guozhen has given us all three payment contracts

and their dates and which he treats as typical (1988: 275-6) I assumed, for argument's sake, that the original price was $80 \%$ of what a permanent sale would have cost, and further assumed an annual interest rate of $12 \%$, which is far below the rates usually quoted for credit in the village: the buyer still comes out far ahead, having 76.8 more taels of silver at the time of the final payment (25 years later) than he would if had made a permanent purchase at the outset. If we raise the hypothetical interest rate to the levels typically available in rural money markets (36\% per year is often used, though these loans of course entailed some risks), the profit from buying through live sale becomes much greater still. In the documents for another case provided by Cohen (2004: 49-50), the same calculation comes out even more strongly in favor of the buyer. And Zelin (1986: 516) even cites one case in Sichuan in which the living sale price was less than a quarter of the land's market value.

It would appear, then, that sellers in these transactions were actually purchasing a fairly expensive form of insurance and/or paying a substantial amount to avoid as long as possible the social embarrassment of having lost land they had inherited. Moreover, since the state would not generally enforce payment of the "insurance" benefit, the value of the insurance was open to some question. (A Qing sub-statue of 1740 did provide for the middleman to negotiate a one-time supplemental payment when outright sale had not been specified, but did not contemplate any payments beyond that. Buoye 2000: 96.) Indeed, to make sense of some of these transactions from the seller's point of view would seem to require assuming that another kind of insurance was at work: some sort of understanding (which does seem to have been common though not universal) that as long 
The Rise, Organization, and Institutional Framework of Factor Markets, 23-25 June 2005 http://www.iisg.nl/hpw/factormarkets.php

as the sale was not yet final, the seller could remain as tenant. But for this to be a crucial factor, tenancies would have had to be hard to come by otherwise, which is not likely to have been the case when live sales were first becoming established; conceivably, increased population pressure eventually gave a new purpose to a practice originally related to an idea of land as patrimony, but this is guesswork. Moreover, the desire to hold on to a chance to rent cannot explain the significant minority of cases Buoye found in which people making conditional sales used the money so obtained to enter commerce and leave the village (2000: 94-5). Perhaps such people hoped to make a killing, return, and buy back their land, and were willing to have a smaller stock of initial capital if that insured that a specific plot they were attached to would remain available for repurchase; but this, too, is highly speculative. Finally, one can imagine - though there is no evidence of this - that relatives who might have tried to block a definitive sale of somebody's land to an outsider were more willing to acquiesce in a live sale - but if they acted this way without later helping their relative repurchase the land, they were seriously harming him without benefiting themselves. There may simply be no one explanation that covers most of the many sellers choosing to make "live sales."

The buyer's choice, on the other hand, does not seem to require very much explanation unless we assume an extreme aversion to risk: they acquired land cheaply and probably rarely had to sell it back. It is also worth noting that requests for additional payments many years after the transaction, though no doubt exasperating (and the apparent cause of some ultimately fatal arguments), were, in economic terms, rather unimportant in a world with high interest rates. Indeed they would seem a rather cheap way of gaining local status as a "patron" of sorts - which of course does not mean that 
The Rise, Organization, and Institutional Framework of Factor Markets, 23-25 June 2005 http://www.iisg.nl/hpw/factormarkets.php

every candidate wished to buy that status, even at fire-sale prices. So when the Qing focused their efforts to reform huomai and dianmai transactions on shortening the number of years that such transfers could remain open (see for instance Yang 1988: 35), they were attacking the aspects of the system that concerned them the most: its tendency to produce both litigation backlogs and arguments ending in violence. (Macauley 1998: 228-9, 238.) Had their concern been to protect the interests of buyers and/or maximize the efficiency of land markets (which was probably a minor part of their thinking, at best) these initiatives would have been both largely unnecessary and largely irrelevant.

Rights to permanent tenancy (aka topsoil rights or "skin of the land" pitian), which will be discussed below, were also sometimes sold in huomai transactions. In the few examples of such transactions that I have seen (from $18^{\text {th }}$ century Guangdong, Zhejiang and Jiangsu, all quoted in Zhou and Xie 1986, 311-317), the redemption date in the contract appears to have been more important than it often was in other live sales. Both money to buy back these rights and requests for additional payment generally seem to have been presented just at the end of the period provided for by the original contract, and in one case, a buyer successfully resisted a request for an additional payment on the grounds that the contract period had not yet expired. While this is a very thin evidentiary base, it is possible that in these cases contracts were followed more precisely and any right that the seller gained to seek future assistance was less diffuse. This would make sense insofar as sales of topsoil rights alone were seen as more strictly economic transactions, not implicating issues relating to social status and land as patrimony, while transactions involving full title to the land probably still raised such issues for some people. 
The Rise, Organization, and Institutional Framework of Factor Markets, 23-25 June 2005 http://www.iisg.nl/hpw/factormarkets.php

$\underline{\text { Rights of tenants and multiple ownership of land: }}$

Along with "live sales," the most distinctive and important feature of late imperial and Republican land markets was the development of various forms of permanent tenancy: the right of a tenant to continue indefinitely using a particular field as long as he paid the rent. Contracts with this feature begin to appear in the Ming, and in a few places (mostly in the Southeast) they had become quite common by the Wanli (1572-1620) period. (Yang 1988: 92-93; Zhou and Xie 290-292.) The contracts generally included a provision fixing the level of rent (in cash, kind, or share), since if the rent can be raised without limit, the right to a permanent tenancy would be worthless; at first, however, they generally forbade the permanent tenant to sublet the land. By the early Qing, however, permanent tenancy or "topsoil rights" had also become marketable property, and such rights changed hands for cash fairly frequently. Where these topsoil rights had become recognized as just as established as the rights of the subsoil owner, the resulting system was generally know as "one field, two masters (yitian liangzhu)." A similar system evolved for privately-owned lakes and ponds, with the right to raise fish in the water becoming separable from the right to receive rent from the person doing so. (Yang 1988: 131.)

Not surprisingly, landlords were not particularly eager to see their rights to choose tenants diminished in this way; nor, at first, was the state. Generally speaking, it appears that first permanent tenancy and then yitian liangzhu emerged through private contracts (which often, though not always, included the payment of a substantial rent deposit - see for instance Zhou and Xie 1986: 297). It then became local custom when 
The Rise, Organization, and Institutional Framework of Factor Markets, 23-25 June 2005 http://www.iisg.nl/hpw/factormarkets.php

some combination of circumstances increased the bargaining power of tenants: when the aftermath of civil war produced a shortage of labor and a need for work to restore ruined fields, when landlords moved into town and became less able to directly supervise their land, etc. Institutional landlords - schools, temples, the military, corporations dedicated to the support of lineage sacrifices - often accepted permanent tenancy rights (and de facto, if not officially, allowed them to be bought and sold), presumably as a way of minimizing the work of supervision. (Zhou and Xie 1986: 299-301.) At some point or other, however, at least some landlords were bound to resist tenants asserting such rights (with or without contract); the state seems to have come down on the side of tenants when conflict was widespread, concluding that allowing significant security for tenants who were meeting their basic obligations was the best way to preserve social stability (e.g. Zhou and Xie 1986: 292, 295). (As we will see, however, the state almost always defended evictions of tenants who were delinquent in their rent if such cases came to them, except in cases of severe harvest failure; in some places, the late Qing state even became involved in dunning tenants for rent.) Even in the absence of collective action, individual tenants sometimes gained permanent tenancy rights (and state recognition thereof) through undertaking reclamation or improvement projects that substantially raised the value of the land, even if such rights were not common on most of the land in their area; it is not clear how often those rights evolved further into yitian liangzhu. (Zhou and Xie 1986: 296.)

It is important to note that this system was far from universal; its complications (which both make it intrinsically interesting and the subject of many disputes which generated documents) have increased scholarly attention to it, but a great deal of the land 
The Rise, Organization, and Institutional Framework of Factor Markets, 23-25 June 2005 http://www.iisg.nl/hpw/factormarkets.php

rented in China continued to be rented on short-term contracts, and/or without any written

contract at all. (Moreover, most land in China was farmed by its owners, particularly in the North.) It was, however, particularly common in China's most productive areas during the Qing; and it appears to have been given a further boost when the massive death and destruction of the Taiping Rebellion (which was concentrated in the relatively wealthy Middle and Lower Yangzi regions) made labor temporarily scarce and the restoration of fields and irrigation works urgent. A survey in the 1930s claimed that $90 \%$ of rented land in Suzhou was covered by yitian liangzhu, and $80 \%$ in nearby Changshu; the percentage dropped to $50 \%$ in nearby Wuxi however (still well within the Yangzi Delta region). Other areas in which this system was well-established were in heavily commercialized parts of Fujian and Guangdong and on Taiwan (essentially an offshoot of Fujian). One of the few other places in which it was found was in the immediate surroundings of Tianjin: an intensely commercialized and relatively prosperous area amdist the generally much poorer Northern plain..

This geographic pattern has led Yang Guozhen to argue that yitian liangzhu was a natural outgrowth of higher levels of development, which weakened the hand of landlords who received rents without being directly involved in the production process (1988: 94-100, 130-131). While the story is not quite that simple - in part of the Yangzi Delta, for instance, landlords may have withdrawn from directly supervising farming, but many of them still played a direct role in managing irrigation works which were essential to farming (e.g. Elvin 1977) - it is true both the control of production and rights over the land tended, over time, to move towards the actual cultivators. Even when institutional changes occurred that gave landlords more leverage - for instance, the rise of rent 
The Rise, Organization, and Institutional Framework of Factor Markets, 23-25 June 2005 http://www.iisg.nl/hpw/factormarkets.php

collection bureaus often closely tied to the local police and to special debtors' prisons in the late Qing Yangzi Delta (Muramatsu 1966; Bernhardt 1992) - their efforts centered on punishing individual tenants who underpaid their contractual rents. There does not seem to have been any serious effort to undermine yitian liangzhu as an institution. Collective protests by tenants were largely focused on the issue of securing rent reductions in bad years (Bernhardt 1992); while it is quite possible that some of the peasants involved feared eviction and loss of their permanent tenant status if they failed to lower the rent for a given year, that issue is not highlighted in their petitions.

The rents that subsoil owners could charge were not, in fact, completely fixed, though they were certainly sticky; manipulation of the rate at which rents set in kind were converted to cash offered one way around them (Bernhardt 1992: 142ff). For his and other reasons, Bernhardt's claim that being a landlord was inexorably becoming unprofitable seems extreme. ${ }^{5}$ Nonetheless, the general direction of change over the long haul does seem to have been in the direction for a stronger position for tenants in the most advanced regions, who were the most likely to have permanent tenancy rights; this security seems to have been adequate to induce high levels of investment and land improvement by tenants (or in some cases, sub-tenants).

Unsurprisingly, tenants without permanent tenancy rights faced greater insecurities, and they made up a large share of the tenants in many poorer parts of China. (However, tenants of any sort generally farmed less of the land in these regions than in the most developed regions: perhaps $15 \%$ in North China, for instance, versus almost half in the Yangzi Delta and over half in the Pearl River Delta.) Even in Guangdong, where

\footnotetext{
${ }^{5}$ Bernhardt 1992: 219-224, 231-2. The argument rests heavily on the way in which landlords were squeezed between stagnant or falling rents and rising taxes during the Depression years and the the civil war years of 1945-9, neither of which seem to me logically necessary culminations of a long-term trend.
} 
The Rise, Organization, and Institutional Framework of Factor Markets, 23-25 June 2005 http://www.iisg.nl/hpw/factormarkets.php

permanent tenancy was relatively common, disputes over rent arrears and evictions for

other reasons were, along with water rights disputes, the most common causes of violent conflicts ending in death over the $18^{\text {th }}$ century; while this is not necessarily a reliable indicator of how often tenants were evicted, it is suggestive. (Buoye 2000: 71-128.) Except in cases of very severe harvest failure, magistrates usually supported the right of landlords to evict a tenant for non-payment (or less than full payment) of rent, though he often lost his right to press for payment of the arrears (Buoye 2000: 111, 115). It is not clear whether this pattern was widely enough known to give landlords an added incentive to undertake evictions before the arrears got large in cases where there was no rent deposit; since tenants tended to pay partial rent rather than refusing to pay any rent (Zhou and Xie 1986:376-8; Bernhardt 1992: 27-39, 195), but the costs of eviction were often significant, the calculation of whether and when to remove such a tenant must often have been quite complex. In cases where there was a rent deposit, landlords (who would be obligated to return the deposit when evicting the tenant, and who usually had the deposit invested in something else) tended to wait until arrears equaled the deposit before attempting eviction; this often allowed such tenants to grant themselves rent reductions, though the practice was illegal. (See e.g. Bernhardt 1992: 29.)

As the $18^{\text {th }}$ century wore on, Buoye finds, disputes over rent arrears and other causes of eviction changed their character. Early in the century, tenants frequently fought with landlords or their representatives, and not infrequently gathered support from other members of the community. By the latter part of the century, however, violence was more likely to erupt between a displaced tenant and his replacement, and few other people were involved. Buoye argues - convincingly to me - that this reflects two 
The Rise, Organization, and Institutional Framework of Factor Markets, 23-25 June 2005 http://www.iisg.nl/hpw/factormarkets.php

important trends. On the one hand, rapid population growth weakened tenants'

bargaining power, so that it was more costly for a potential replacement tenant to turn up his nose when offered a rental that involved both some personal risk and the costs of violating whatever class solidarity existed. Even more importantly, he argues, the idea that land was something special, which should not simply go to the highest bidder, weakened over the course of the century, so that those who resisted such transfers eventually became isolated and unable to gather a crowd in their support. (Buoye 2001: $111,115,123-7,192,225-6$.) The same transition, he suggests had probably occurred somewhat earlier in Shandong, and would occur somewhat later in Sichuan. (2000: 153192.) But since Buoye ends his study circa 1800 , it is not clear whether what he has shown us is a once and for all transition from "moral economy" to "rational economy," or part of a much longer and less linear pattern of shifting norms. (For an arument that "moral economy" concerns were very much alive in $20^{\text {th }}$ century Guangzhou see Marks 1984.) For some areas, however, we do have studies focusing on events in later periods, which look very different from the relatively successful entrenchment of tenant rights that Bernhardt sees in the Yangzi Delta.

Though no single area of China is "typical," Baxian, Sichuan - where agriculture was not much commercialized and by-employments were few until the late $19^{\text {th }}$ century, and for which the archival records are unusually rich - may not be a bad representative of less prosperous areas during the Qing. Here, landlords stayed on the land, and tenants' bargaining position seems to have been closely tied to demography: relatively good in the early Qing (in the aftermath of severe depopulation), but becoming increasingly grim over the course of the $18^{\text {th }}$ and early $19^{\text {th }}$ centuries. Permanent tenancy did not take hold 
The Rise, Organization, and Institutional Framework of Factor Markets, 23-25 June 2005 http://www.iisg.nl/hpw/factormarkets.php

to any substantial degree here. Without it, even if tenants had paid a substantial rent deposit - as more and more tenants did over the course of the Qing - landlords were free to remove them, provided they returned the deposit, and many landlords flouted even that requirement. ${ }^{6}$ (Zelin 1986: 512) Under the circumstances, tenants had little incentive to invest in improvements, and while it might seem that landlords would have had such incentives, Zelin cites some limited evidence to suggest that they did not do so either (1986: 524 n. 32); it is possible that the area's population density made it sufficiently profitable to just keep turning over tenants.

\section{$\underline{\text { Assessing late imperial land markets }}$}

At least in China's more developed areas, land markets seem to have functioned fairly well. Per acre yields rose slowly but continually in the late imperial Yangzi Delta, and quite sharply in the most commercialized parts of Guangdong and Fujian, despite very long histories of sustained and intensive use. The incomes of tenants and ownercultivators in the Yangzi Delta were probably fairly flat after 1600, with higher incomes per acre offset by shrinking farm size; but Delta incomes seem to have begun this period at such a high level (in comparative terms) that cultivators here remained among the bestoff in the world until the $19^{\text {th }}$ century. (See for instance Allen 2004, Allen 2005.) While even the richest parts of China failed to keep that position thereafter, this seems to be due to the slow development of non-farm sectors. The problem was not with agricultural

\footnotetext{
${ }^{6}$ The failure to return a deposit may have sometimes reflected that what we call "deposits' were seen by the landlords as a portion of the rent, paid in advance. Zelin (1986: 513) cites an instance in which a landlord suddenly demanded that a long-time tenant double his deposit, while at the same time he cut the annual tenant's annual rent by almost 80\%. (See also Rawski 1972: 123.) Moreover, rent deposits were commonly used by landlords as capital for other ventures - some of which would have then been illiquid at the moment a dispute with a tenant arose. The authorities seem to have been particularly tolerant of widows who suddenly raised the deposits on land their husbands had owned after their husbands died, often alluding to funeral expenses (Zelin 1986: 514) - which again, presumably reflects a view of these "deposits" as part of rent rather than simply a hedge against default.
} 
The Rise, Organization, and Institutional Framework of Factor Markets, 23-25 June 2005 http://www.iisg.nl/hpw/factormarkets.php

incomes, at least up to 1800 or so. Nor, given the rents that tenants paid- $50 \%$ of the main crop seems to have been about average - does it make much sense to assume that agriculture failed to generate a potentially investible surplus adequate for broader development, even in the $19^{\text {th }}$ and early $20^{\text {th }}$ centuries. In other words, these areas do not seem to present the sort of situation Van Zanden found in Java ca. 1815, where relatively high labor incomes in agriculture reflected a very high factor share for labor and so disguise a lagging agriculture overall. (Van Zanden 2003)

Another type of indicator also suggests that land markets in at least East China were quite efficient. In John Buck's survey of Chinese farms in the 1920s (Buck 1930: 114), farm labor earnings per man-equivalent differed very little for different sizes of farms in his Zhejiang and Jiangsu samples, suggesting that as the labor available to different families rose and fell over time, they were able to make contracts that adjusted the amount of land they farmed accordingly. Farms in the North and Northwest showed a much larger advantage in labor returns per laborer for those with larger farms. (The one county surveyed in Fujian, however, resembled the North China pattern, not that of the

\section{Lower Yangzi.)}

This difference may reflect a number of features of the North and West not strictly related to the land market - fewer off-farm opportunities to absorb "excess" labor, fewer ways to increase labor inputs per acre without sharply diminishing returns in environments with limited amounts of water, and so on - and it is hard to see exactly what features of the relatively straightforward land markets in, say, North China we would blame for these problems. Still, it is striking that returns to labor were more even across farm sizes in the Southern and Eastern regions where strong lineages, restrictions 
The Rise, Organization, and Institutional Framework of Factor Markets, 23-25 June 2005 http://www.iisg.nl/hpw/factormarkets.php

on sales to non-kin, permanent leases, and so on are often said to have interfered with rural land and labor markets, stifling dynamism and development (e.g. Huang 1990, Brenner and Isett 2002).

Similarly, it would be a mistake to blame the lag in agricultural investment in a region such as North China on the institutions of the land market, particularly since most plots there were cultivated by their owners whose incentives to make productivityincreasing investments would have been strong; it is more likely that there just were not very many such investments available prior to basin-wide flood control schemes and the availability of power-driven water pumps. (See, for instance, Greer 1979, Pietz 2002.) But again, it is striking that the regions in which some scholars have been particularly prone to see institutional distortions are the ones in which heavy investments were generally made. North and West China certainly had agricultural problems but they appear to have been matters of ecology, demography, and technology, not of the land market.

\section{Coda: Rural Disorder and the Land Market}

A final issue, which is particularly resistant to measurement, is whether some of the uncertainties surrounding land transfers - particularly live sales and the weakness of state property registration - hurt agriculture in a different way, by provoking conflicts that increased losses from violence. Since much of what we know about the actual mechanics of land sales comes from cases that led to conflicts (and thus wound up in the archives) one can get this impression, but it seems to me unlikely that laws and customs surrounding land per se get should much of the blame. At least in $18^{\text {th }}$ century Guangdong, the land related issues that led to the most violence were boundary disputes, 
The Rise, Organization, and Institutional Framework of Factor Markets, 23-25 June 2005 http://www.iisg.nl/hpw/factormarkets.php

rent resistance and tenant evictions: these were all issues on which the laws were fairly clear, and about which conflicts can be expected in almost any society in which it does not seem hopeless for people to press their interests beyond their legal rights. The one possible exception here might be arguments over rent reductions in bad years, where claims of right were made on both sides - but this is a case, at least in Jiangnan, where effective strategies to contain most conflicts short of violence seem to have been worked out. (Bernhardt 1992.) In other common conflicts - with the possible exception of water rights, which I have not explored here ${ }^{7}$--it was probably the state's unwillingness or inability to enforce most judgments, not inability of parties to get a judgment within a reasonable time or to predict what it would be, that was usually the reason that they turned to other means of "settlement," as Buoye points out. (Buoye 2000: 193-218; see also Osborne 2004: 156.) We do not have comparable studies for the $19^{\text {th }}$ century, but it at least seems that the most common sources of land-related violence in Southeast China during those years involved lineages fighting over land reclamation, especially polders along the coast (Wakeman 1966, Kuhn 1970); this was land that had not yet entered the market at all. It is also important here to be cautious about taking too literally claims of rampant rural violence and disorder, at least prior to 1800 . The Qing pointed repeatedly to Fujian as a particularly lawless province, blaming powerful lineages and their propensity to war over land and water; but the reported homicide rate for Fujian at midcentury (roughly 1.5 per 100,000 per year, while it was anywhere from 2 to 5 times that recorded in other provinces (Macauley 1998:274-5), was roughly in line with most of our estimates for the West at the same time.

\footnotetext{
${ }^{7}$ Qing statutory law on water rights does seem to have been rather imprecise, and at least in some areas, water was a frequent source of conflict. But thus far we know too little about how local societies allocated water for any strong generalizations.
} 
The Rise, Organization, and Institutional Framework of Factor Markets, 23-25 June 2005 http://www.iisg.nl/hpw/factormarkets.php

Homicide rates are, of course, only a very rough indicator of more general levels of insecurity, and the Qing do seem to have done much less than many early modern states in the West to make the state the everyday arbiter and protector of property rights. As we have seen, it did serve as arbiter of disputes when necessary, and its decisions seem to have generally been consistent with what emerged through other kinds of adjudication. At least in the case of the land market, it does not appear that the efficiency of the economy suffered much from relying primarily on these other ways of doing business and judging the disputes that emerged. Whether the same can be said about the state's willingness to leave so much of the enforcement of property-related rules to local informal mechanisms remains an open question. But it does seem that as long as violence did not come into play, late imperial land markets functioned reasonably well. 
Bibliography

Allen, Robert. 2005. "Agricultural Productivity and Rural Incomes in England and the Yangzi Delta, ca. 1620-1820." Available at http://www.economics.ox.ac.uk/Members/robert.allen/default.htm

Allen, Robert. 2004. "Mr Lockyer Meets the Index Number Problem: the Standard of Living in Canton and London in 1704." Available at

http://www.economics.ox.ac.uk/Members/robert.allen/default.htm

Bernhardt, Kathryn. 1992. Rents, Taxes, and Peasant Resistance: The Lower Yangzi Region, 1840-1950. Stanford: Stanford University Press.

Brenner, Robert, and Isett, Christopher. 2002. “England's Divergence From China's Yangzi Delta: Property Relations, Microeconomics and Patterns of Development." Journal of Asian Studies 61:2 (May): 609-662.

Brook, Timothy. 1998. The Confusions of Pleasure: Commerce and Culture in Ming China. Berkeley: University of California Press.

Buck, John L. 1930. (1971). Chinese Farm Economy. Chicago: University of Chicago Press. Reprinted by University Microfilms, Ann Arbor, 1971.

Buoye, Thomas. 2000. Manslaughter, Markets, and Moral Economy: Violent Disputes over Property Rights in Eighteenth Century China. Cambridge: Cambridge University Press.

Campbell, Cameron, and Lee, James. 2003. "Social Mobility From a Kinship Perspective: Rural Liaoning, 1789-1909." International Review of Social History, 48 (part 1): 1-26.

Chen, Fu-mei and Ramon Myers. 1976. "Customary Law and the Economic Growth of China during the Ch'ing Period." Ch'ing shih wen-t'i 3:5: 1-32..

Cohen, Myron. 2004. "Writs of Passage in late Imperial China: The Documentation of Practical Understandings in Minong, Taiwan." In Madeleine Zelin, Jonathan Ocko, and Robert Gardella, eds., Contract and Property in Early Modern China (Stanford: Stanford University Press), pp. 37-93.

Dennerline, Jerry. 1986. "Marriage, Adoption, and Charity in the Development of Lineages in Wu-his from Sung to Ch'ing." In Patricia Ebrey and James Watson, eds., Kinship Organization in Late Imperial China 1000-1940 (Berkeley: University of California Press), pp.170-209.

Duara, Prasenjit. 1988. Culture, Power and the State: Rural North China 1900-1942. Stanford: Stanford University Press. 
The Rise, Organization, and Institutional Framework of Factor Markets, 23-25 June 2005 http://www.iisg.nl/hpw/factormarkets.php

Elvin, Mark. 1977. "Market Towns and Waterways: the County of Shanghai from 1480 to 1910." In G. William Skinner, ed., The City in Late Imperial China (Stanford: Stanford University Press),

Feng Shaoting. 2004. "Supplemental Payments in Urban Property Contracts in Mid to Late Qing Shanghai." In Madeleine Zelin, Jonathan Ocko, and Robert Gardella, eds., Contract and Property in Early Modern China (Stanford: Stanford University Press), pp. 209-229.

Fryson, David. 1999. "Blows and Scratches, Swords and Guns: Violence Between Men as Material Reality and Lived Experience in Early Nineteenth Century Lower Canada." Paper presented at the annual meeting of the Canadian Historical Association, Sherbrooke, June 1999. http://www.fl.ulaval.ca/hst/Profs/Dfyson/Violence.htm

Greer, Charles. 1979. Water Management in the Yellow River Basin of China. Austin: University of Texas Press.

Hansen, Valerie. 1995. Negotiating Life in Traditional China: How Ordinary People Used Contracts 600-1400. New Haven: Yale University Press.

Huang, Philip. 1985. The Peasant Economy and Social Change in North China. Stanford: Stanford University Press.

. The Peasant Family and Rural Development in the Lower Yangzi

Region, 1350-1998. Stanford: Stanford University Press.

Huang, Ray. 1974. Taxation and Government Finance in $16^{\text {th }}$ Century Ming China. Cambridge: Cambridge University Press.

Kuhn, Philip. 1970. Rebellion and its Enemies in Late Imperial China. Cambridge: Harvard University press.

Liang Zhiping. 1996. Qingdai de xiguanfa: shehui yu guojia. (Customary law in the Qing Dynasty: society and nation.) Beijing: Zhonghua zheng fa daxue chubanshe.

McAleavy, Henry. 1958. "Dien in China and Vietnam.” Journal of Asian Studies 17:3 (May) 403-415.

Macauley, Melissa, 1998. Social Power and Legal Culture: Litigation Masters in Late Imperial China. Stanford: Stanford University Press.

Marks, Robert. 1984. Rural Revolution in South China. Madison: University of Wisconsin Press. 
The Rise, Organization, and Institutional Framework of Factor Markets, 23-25 June 2005 http://www.iisg.nl/hpw/factormarkets.php

Muramatsu Yujii. 1966. “A Documentary Study of Chinese Landlordism in Late Ch'ing and Early Republican Kiangnan." Bulletin of the School of Oriental and African Studies 29:3: 566-599.

Niida Noboru. 1960. Chūgoku hōseishi kenkyū. (Studies in Chinese legal history). Volume 2. Tokyo: Tōkyō Daigaku Shuppansha.

Ocko, Jonathan K. "The Missing Metaphor: Applying Western Legal Scholarship to the Study of Contract and Property in Early Modern China." In Madeleine Zelin, Jonathan

Ocko, and Robert Gardella, eds., Contract and Property in Early Modern China (Stanford: Stanford University Press), pp. 178-205.

Osborne, Anne. 1994. "The Local Politics of Land Reclamation in the Lower Yangzi Highlands." Late Imperial China 15:1 (June) 1-46.

. 2004. "Property, Taxes, and State Protection of Rights." In Madeleine Zelin, Jonathan Ocko, and Robert Gardella, eds., Contract and Property in Early Modern China (Stanford: Stanford University Press), pp. 120-158.

Pepper, Suzanne. 1978. Civil War in China: The Political Struggle, 1945-1949. Berkeley: University of California Press.

Pietz, David. 2002. Engineering the State: The Huai River and Reconstruction in Nationalist China, 1927-1937. London: Routledge.

Pomeranz, Kenneth. 1993. The Making of a Hinterland: State, Society, and Economy in Inland North China, 1853-1937. Berkeley: University of California Press.

. 2002. "Beyond the East/West Binary: Resituating Development

Paths in the Eighteenth Century World." Journal of Asian Studies 61:2 (May), pp. 539590.

Rawski, Evelyn. 1972. Agricultural Change and the Peasant Economy of South China. Cambridge: Harvard University Press.

Scogin, Hugh. 1990. "Between Heaven and Man: Contract and the State in Han Dynasty China." Southern California Law Review 63: 1325- 1404.

Szonyi, Michael. 2002. Practicing Kinship: Lineage and Descent in Late Imperial China. Stanford: Stanford University Press.

Van Zanden, Jan Luiten. 2003. "Rich and Poor before the Industrial Revolution: a comparison between Java and the Netherlands at the beginning of the 19th century." Explorations in Economic History 40:1 (January) 1-23. 
The Rise, Organization, and Institutional Framework of Factor Markets, 23-25 June 2005 http://www.iisg.nl/hpw/factormarkets.php

Wakeman, Frederic Jr. 1966. Strangers at the Gate: Social Disorder in South China, 1839-1861. Berkeley: University of California Press.

Yang Guozhen. 1984. "Qingdai Zhejiang tian qi dian yi pie” (A look at land rental contracts in Zhejiang during the Qing dynasty.) Jingji shi 1:101-118.

Yang Guozhen. 1988. Ming Qing tudi qiyue yanjiu. (Research on land contracts in the Ming and Qing.) Beijing: renmin chubanshe.

Zelin, Madeleine. 1986. "The Rights of Tenants in Mid-Qing Sichuan: A Study of LandRelated Lawsuits in the Baxian Archives." Journal of Asian Studies 49:3 (August) 499526.

2004. "A Critique of Rights of Property in Prewar China." In Madeleine Zelin, Jonathan Ocko, and Robert Gardella, eds., Contract and Property in Early Modern China (Stanford: Stanford University Press), pp. 17-36.

Zhou Yuanlian and Xie Zhaohua. 1986. Qingdai zudian zhi yanjiu. (Research on the tenancy system of the Qing dynasty.) Shenyang: Liaoning renmin chubanshe. 